\title{
Pengendalian Waktu Proyek dengan Menggunakan Metode Critical Chain Project Management (Ccpm) (Studi Kasus: Pembangunan Jalan SMK IT Payakumbuh)
}

\author{
Suherman ${ }^{1)}$, Ade Aulia ${ }^{2}$ \\ ${ }^{1,2}$ Jurusan Teknik Industri, Fakultas Sains dan Teknologi, UIN Sultan Syarif Kasim Riau \\ Jl. HR. Soebrantas No. 155 Simpang Baru, Panam, Pekanbaru, 28293 \\ Email: suher_aje@yahoo.co.id
}

\begin{abstract}
Abstrak
Penelitian ini dilakukan untuk membuat perencanaan proyek jalan SMK IT Payakumbuh yang diharapkan tidak seperti proyek sebelumnya, dimana terjadi ketidaksesuaian antara perencanaan dan pelaksanaannya. Hal ini dikarenakan ada beberapa pekerjaan yang overlapping. Oleh karena itu dibuat penjadwalan ulang dengan menggunakan metode Critical Project Management(CCPM). Dari data primer dan sekunder diolah dengan software microsoft project 2007. Metode ini menghilangkan waktu aman (Safety Time) dan menggantinya dengan waktu penyangga (Buffer Time). Penambahan buffer time dengan menggunakan metode cut and paste yaitu menambahkan project buffer separuh durasi rantai kritis (critical chain) pada akhir rantai dan meletakan feeding buffer dengan separuh durasi aktivitas ke aktivitas pada rantai tidak kritis (non critical chain). Hasil dari penelitian bahwa apabila saat proyek berjalan tidak terdapat perubahan-perubahan maka proyek dapat diselesaikan selama 147 hari kalender. Apabila terjadi ketidaksesuaian, maka buffer time dapat dikonsumsi sebesar 10 minggu dan total penyelesaian proyek selama 197 hari kalender, waktu aman untuk proyek pembangunan jalan SMK IT Payakumbuh ini.
\end{abstract}

Kata Kunci: Critical Chain Project Management, Project Buffer, Buffer Time, Feeding Buffer

\section{Pendahuluan}

Permasalahan dalam bidang konstruksi pada saat ini yang sering terjadi adalah pada tahap pelaksanaan sering terjadi perubahan yang mengakibatkan keterlambatan penyelesaian, sehingga waktu penyelesaian proyek tidak sesuai dengan waktu perencanaan awal proyek tersebut. Oleh sebab itu, proyek tidak berjalan dengan lancar dan mengakibatkan penambahan biaya yang melebihi dari perencanaan, sehingga ada proyek yang tertunda atau tidak dapat di lanjutkan. Dalam hal ini dibutuhkan perencanaan penjadwalan proyek yang lebih baik sehingga proyek dapat berjalan sesuai dengan rencana yang telah disusun dan tidak menyebabkan penambahan biaya proyek, sehingga proyek tertunda. Dalam suatu proyek pembangunan, perencanaan merupakan masalah yang sangat penting.

Metode Critical Chain Project Management menurut Goldratt, 1997 Eliyahu M. dalam bukunya Critical Chain, Pada metode Critical Chain Project Manage-ment ini penambahan waktu aman (safety time) yang biasanya diletakkan pada setiap aktivitas akan dihilangkan dan digantikan dengan waktu penyangga (buffer time) yang diletakkan diakhir critical chain sebagai cadangan waktu pada keseluruhan proyek. Apabila hal-hal yang tidak pasti (uncertainty) terjadi saat pelaksanaan proyek, maka dapat diantisipasi dengan adanya waktu penyangga (buffer time) sehingga terhindar dari keterlambatan (Rohana, 2014).

Penelitian ini mengambil studi kasus pada perusahaan kontruksi pembangunan jalan di Payakumbuh, yaitu CV. Rafli Kontraktor. Sebelumnya,CV. Rafli Kontraktor menangani proyek peningkatan jalan lingkung jalan tanjung yang dilaksanakan selama 9 minggu yang dimulai dari 18 Agustus 2014, ternyata pada pelaksanaannya terjadi keterlambatan. Dapat dilihat seperti pada gambar dibawah ini.

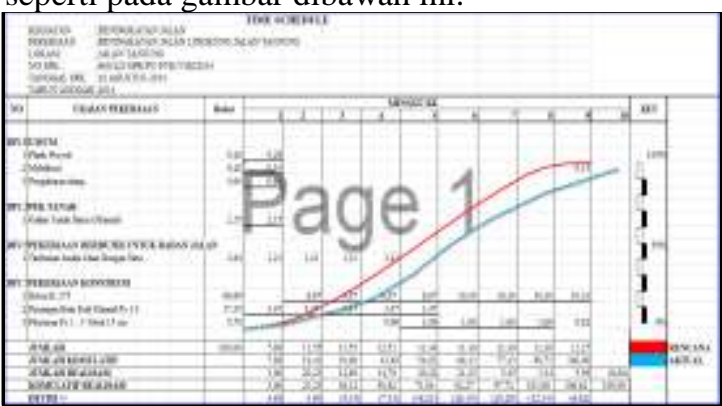

Gambar 1 Kurva S Proyek Aktual

(Sumber: CV. Rafli Kontraktor) 
Berikut adalah tree diagram penyebab keterlambatan proyek Jalan Lingkung Jalan Tanjung yang diperoleh dari hasil wawancara.

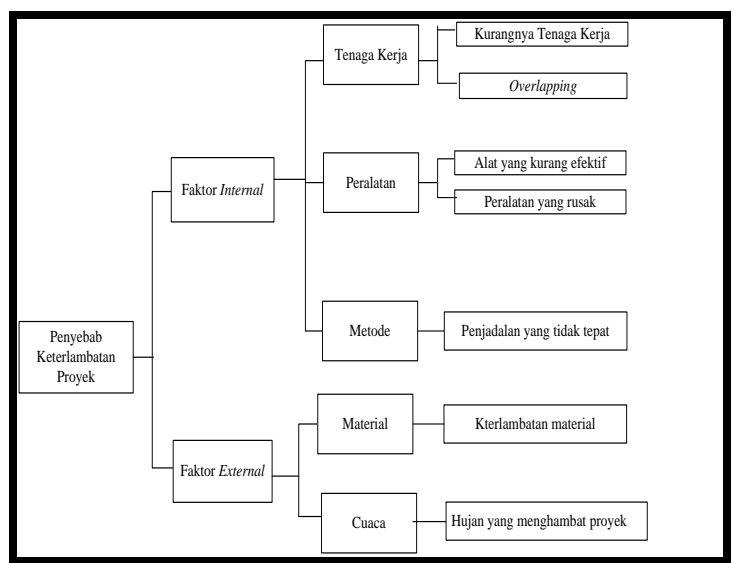

Gambar 2 Tree Diagram Keterlambatan Proyek

Saat ini, CV. Rafli Kontraktor sedang menjalankan proyek yang terletak di Provinsi Sumatera Barat, Kota Payakumbuh. Proyek tersebut meliputi pembangunan jalan SMK IT yang rencananya dilaksanakan selama 147 hari kalender dengan nilai kontrak sebesar Rp. 2.033.638.000. adapun Kurva $\mathrm{S}$ rencana dapat dilihat pada gambar dibawah ini.

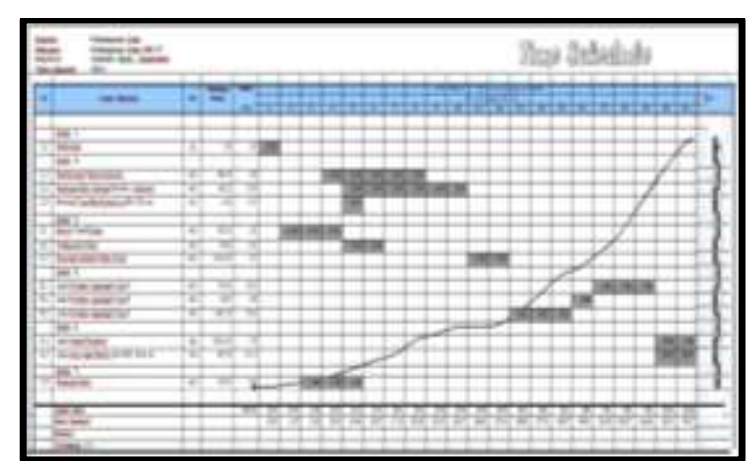

Gambar 3 Kurva S Perencanaan Proyek

(Sumber: CV. Rafli Kontraktor)

Berdasarkan Latar belakang diatas maka dibuatlah penelitian dengan judul "Pengendalian Waktu Proyek dengan Menggunakan Metode Critical Chain Project Management (CCPM) (Studi Kasus: Pembangunan Jalan SMK IT Payakumbuh)".

\section{Metode Penelitian}

Data yang digunakan merupakan data sekunder dan primer. Data sekunder pada penelitian ini meliputi profil perusahaan, master schedule perencanaan proyek dan bill of quantity. Sedangkan data primer pada penelitian ini berupa wawancara dan dokumentasi. Pengolahan data dilakukan dengan melakukan metode Critical Chain Project Management (CCPM) dengan Software Microsoft Project 2007.

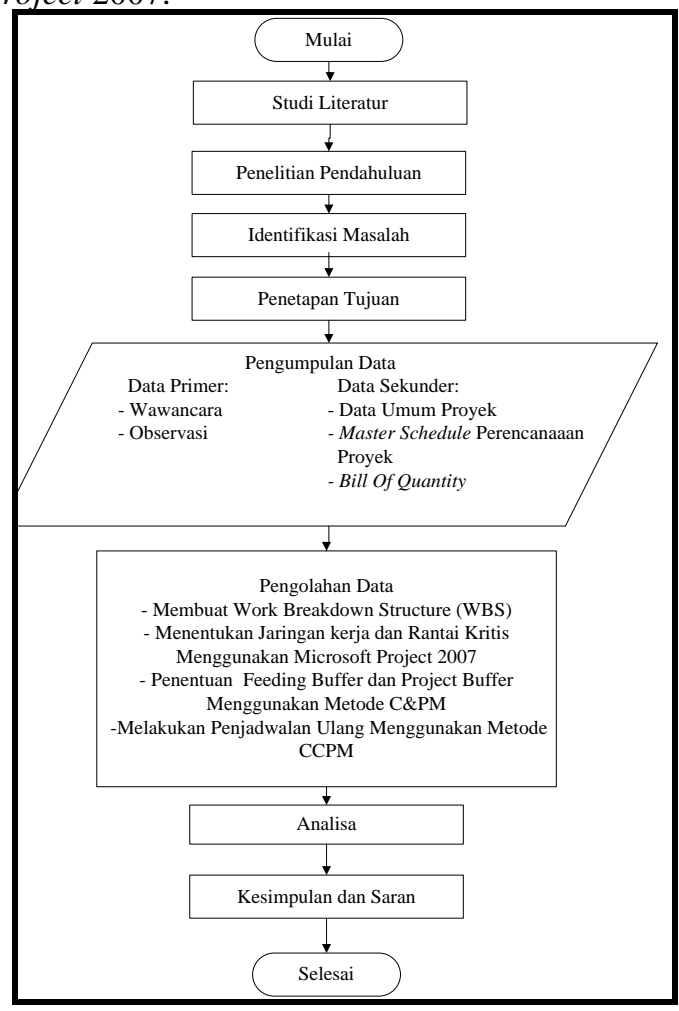

Gambar 4 Flowchart Metodologi Penelitian

\section{Hasil dan Pembahasan}

Berdasarkan pengumpulan data yang telah dilakukan, selanjutnya dilakukan pengolahan sehingga didapatkan hasil dan pembahasan. Berikut adalah hasil dan pembahasan pada penelitian ini.

\section{Pengolahan Data}

Critical Chain Project Management (CCPM) merupakan metode yang digunakan untuk mendapatkan waktu optimal pada perencanaan proyek dengan menghilangkan waktu aman dan menggantinya dengan waktu penyangga. Waktu Penyangga disini didaptkan dengan rumus:

Project buffer $=\Sigma$ rantai kritis $\times 50 \%$

Feeding buffer $=\Sigma$ durasi $(\mathrm{XA}+\mathrm{XB}+\mathrm{XC}) \times 50 \%$ 


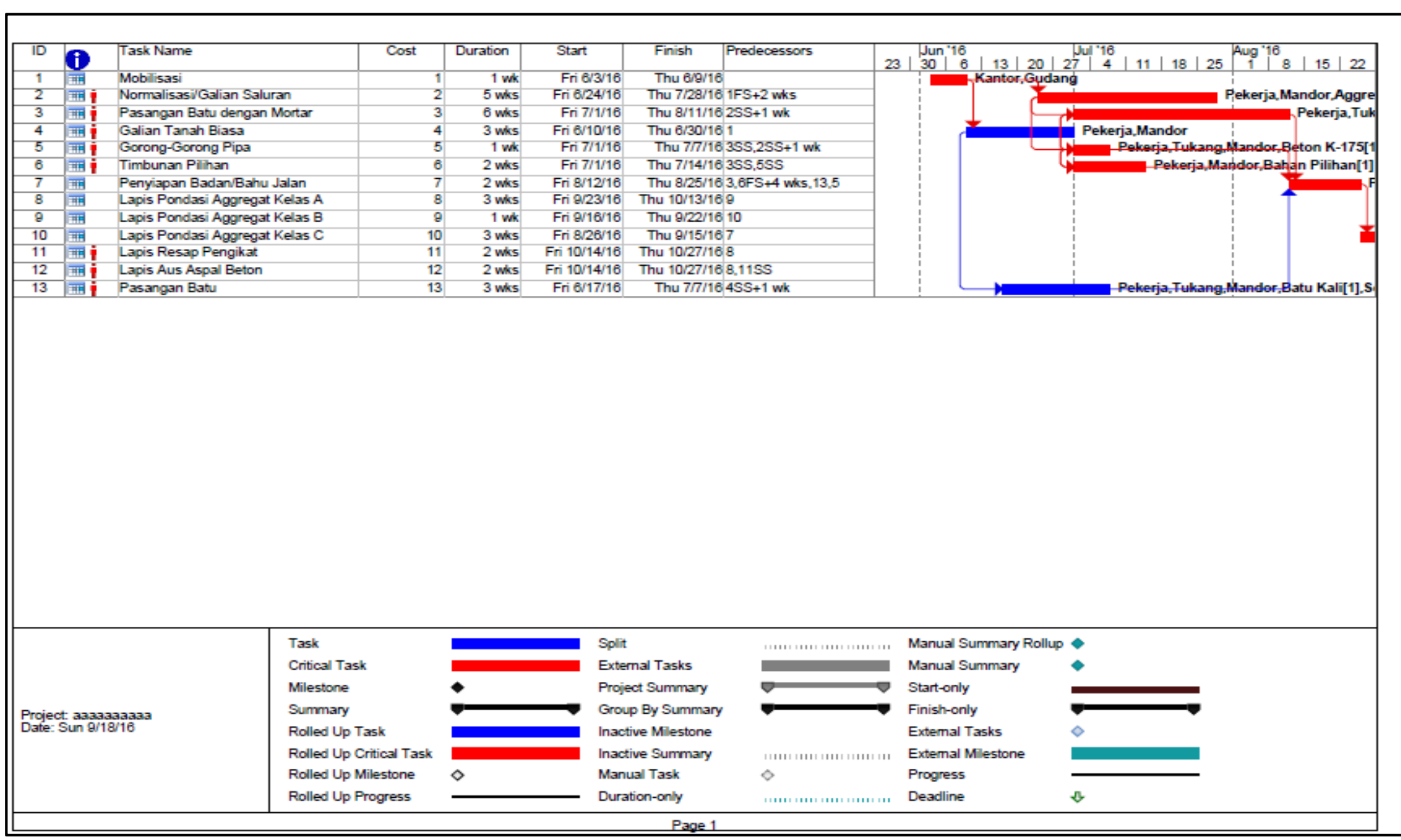

Gambar 5 Hubungan Antar Aktifitas 
Berdasarkan Gambar 5 dapat dilihat bahwa hubungan antar aktifitas proyek SMK IT Payakumbuh Didalam hubungan antar aktivitas ini dapat dilihat lintasan kritis proyek dan hubungan keterkaitan tiap pekerjaan.

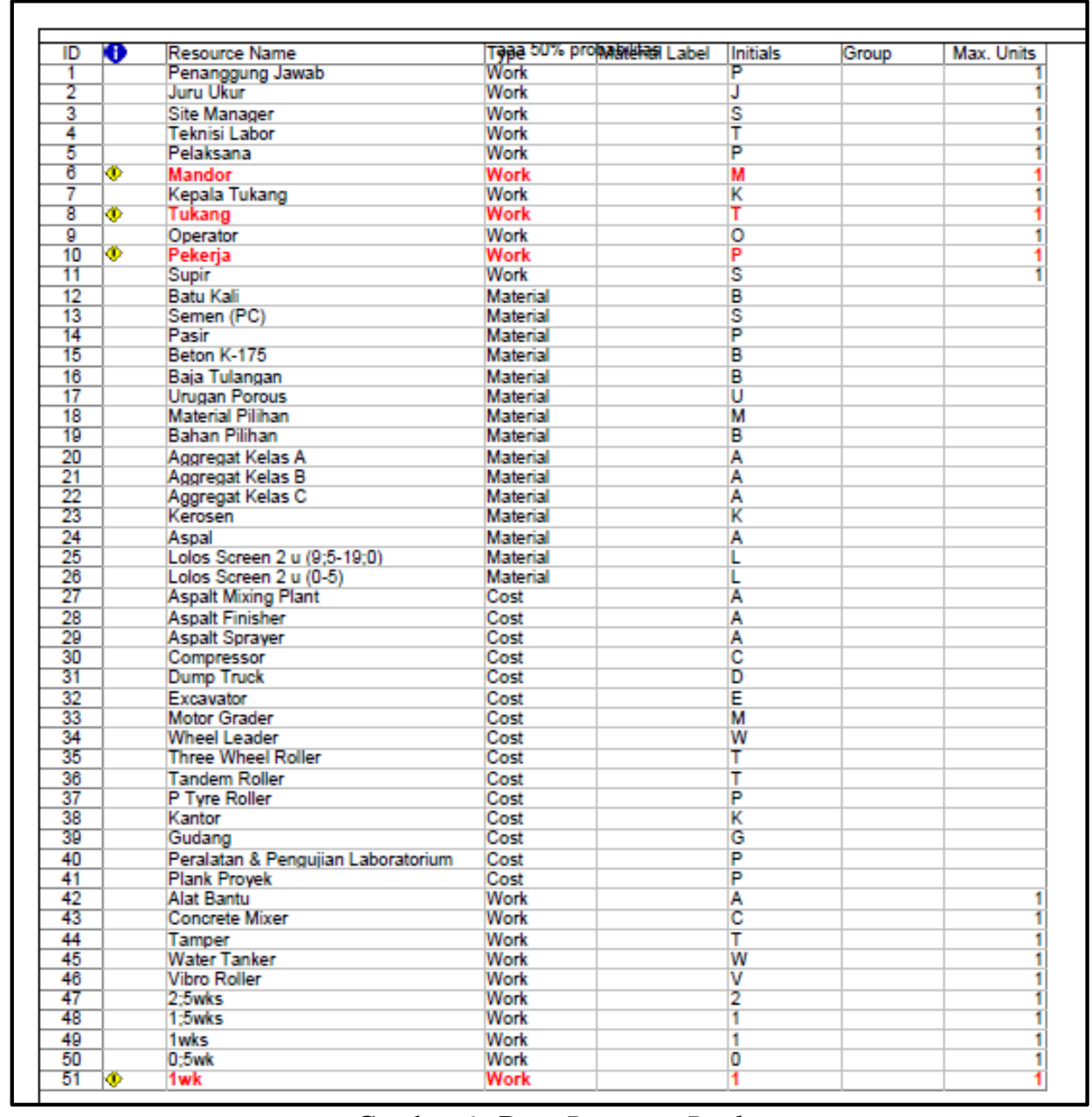

Gambar 6. Data Resource Pool 
Data resourece yang digunakan pada proyek pembuatan jalan SMK IT ini terdiri dari material, tenaga kerja dan biaya. Tenaga kerja didalam proyek ini terbagi atas dua kategori yaitu tenaga kerja langsung dan tak langsung.

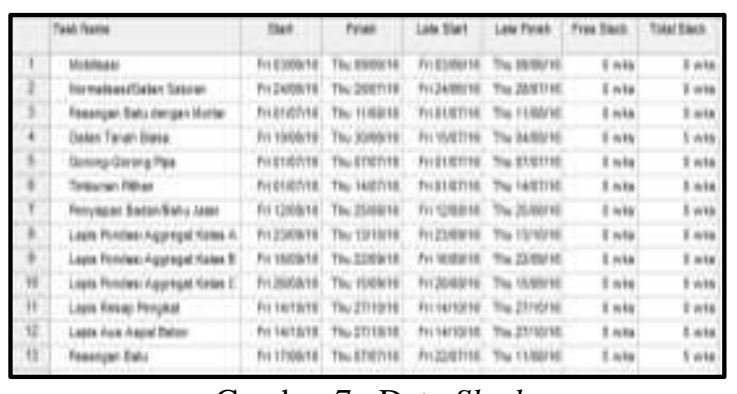

Gambar 7. Data Slack

Dari hasil data pada gambar 4.3 diatas maka jadwal ini memiliki critical path yang diurutkan berdasarkan nomor task name pekerjaan sebagai berikut:

Critical path: 1-2-3-5-6-7-8-9-10-11-12

\section{Perencanaan Penjadwalan dengan Menggunakan Metode Critical Chain Project Management (CCPM)}

\section{Hubungan Keterkaitan Aktivitas}

Hubungan antar aktivitas critical chain ini didasari pada ketergantungan aktivitas itu sendiri. Hubungan keterkaitan ini hanya menggunakan hubungan Finish to Start. Berikut ini adalah data hasil olahan hubungan keterkaitan:

Tabel 1 Data Hubungan Keterkaitan dengan Metode CCPM

\begin{tabular}{|l|l|}
\hline \multicolumn{1}{|c|}{ Task Name } & Predecessor \\
\hline $\begin{array}{l}\text { Normalisasi/Galian } \\
\text { Saluran }\end{array}$ & $1 \mathrm{FS}+2$ wks \\
\hline Galian Tanah Biasa & 1 \\
\hline $\begin{array}{l}\text { Penyiapan Badan/Bahu } \\
\text { Jalan }\end{array}$ & $\begin{array}{l}3 ; 6 \mathrm{FS}+4 \\
\mathrm{wks} ; 13\end{array}$ \\
\hline $\begin{array}{l}\text { Lapis Pondasi Aggregat } \\
\text { Kelas A }\end{array}$ & 9 \\
\hline $\begin{array}{l}\text { Lapis Pondasi Aggregat } \\
\text { Kelas B }\end{array}$ & 10 \\
\hline $\begin{array}{l}\text { Lapis Pondasi Aggregat } \\
\text { Kelas C }\end{array}$ & 7 \\
\hline Lapis Resap Pengikat & 8 \\
\hline Lapis Aus Aspal Beton & $8 ; 11 \mathrm{SS}$ \\
\hline
\end{tabular}

(Sumber: Pengolahan Data, 2016)

Dalam Tabel 4.1 dapat dilihat hubungan keterkaitan dengan menggunakan metode critical chain. Dalam metode critical chain hubungan keterkaitan ini memperhatikan hubungan antara task dengan kondisi sifat pekerjaan itu sendiri. Dengan hubungan finish to start maka terdapat konsekuensi suatu rantai pekerjaan menjadi lebih panjang dibandingkan overlapping. Untuk itu langkah pertama adalah dengan menghilangkan waktu safety dari tiap pekerjaan dengan menggunakan 50\% probabilitas dari waktu pekerjaan untuk menyelesaikan setiap pekerjaan. Berikut pada tabel 4.4 adalah durasi dari aktivitas setelah dihilangkan dengan probabilitas $50 \%$.

Tabel 2. Durasi 50\% Probabilitas Pekerjaan

\begin{tabular}{|l|c|l|}
\hline \multicolumn{1}{|c|}{ Task Name } & $\begin{array}{c}\text { Durasi } \\
\text { (Minggu) }\end{array}$ & Predecessor \\
\hline $\begin{array}{l}\text { Normalisasi/Galian } \\
\text { Saluran }\end{array}$ & 2,5 & 1FS+2 wks \\
\hline $\begin{array}{l}\text { Galian Tanah } \\
\text { Biasa }\end{array}$ & 1,5 & 1 \\
\hline $\begin{array}{l}\text { Penyiapan } \\
\text { Badan/Bahu Jalan }\end{array}$ & 1 & $\begin{array}{l}3 ; 6 \mathrm{FS}+4 \\
\text { wks; } 13\end{array}$ \\
\hline $\begin{array}{l}\text { Lapis Pondasi } \\
\text { Aggregat Kelas A }\end{array}$ & 1,5 & 9 \\
\hline $\begin{array}{l}\text { Lapis Pondasi } \\
\text { Aggregat Kelas B }\end{array}$ & 0,5 & 10 \\
\hline $\begin{array}{l}\text { Lapis Pondasi } \\
\text { Aggregat Kelas C }\end{array}$ & 1,5 & 7 \\
\hline $\begin{array}{l}\text { Lapis Resap } \\
\text { Pengikat }\end{array}$ & 1 & 8 \\
\hline $\begin{array}{l}\text { Lapis Aus Aspal } \\
\text { Beton }\end{array}$ & 1 & $8 ; 11 \mathrm{SS}$ \\
\hline Sumber Pengolahan Data & $2016)$ \\
\hline
\end{tabular}

(Sumber: Pengolahan Data, 2016) 


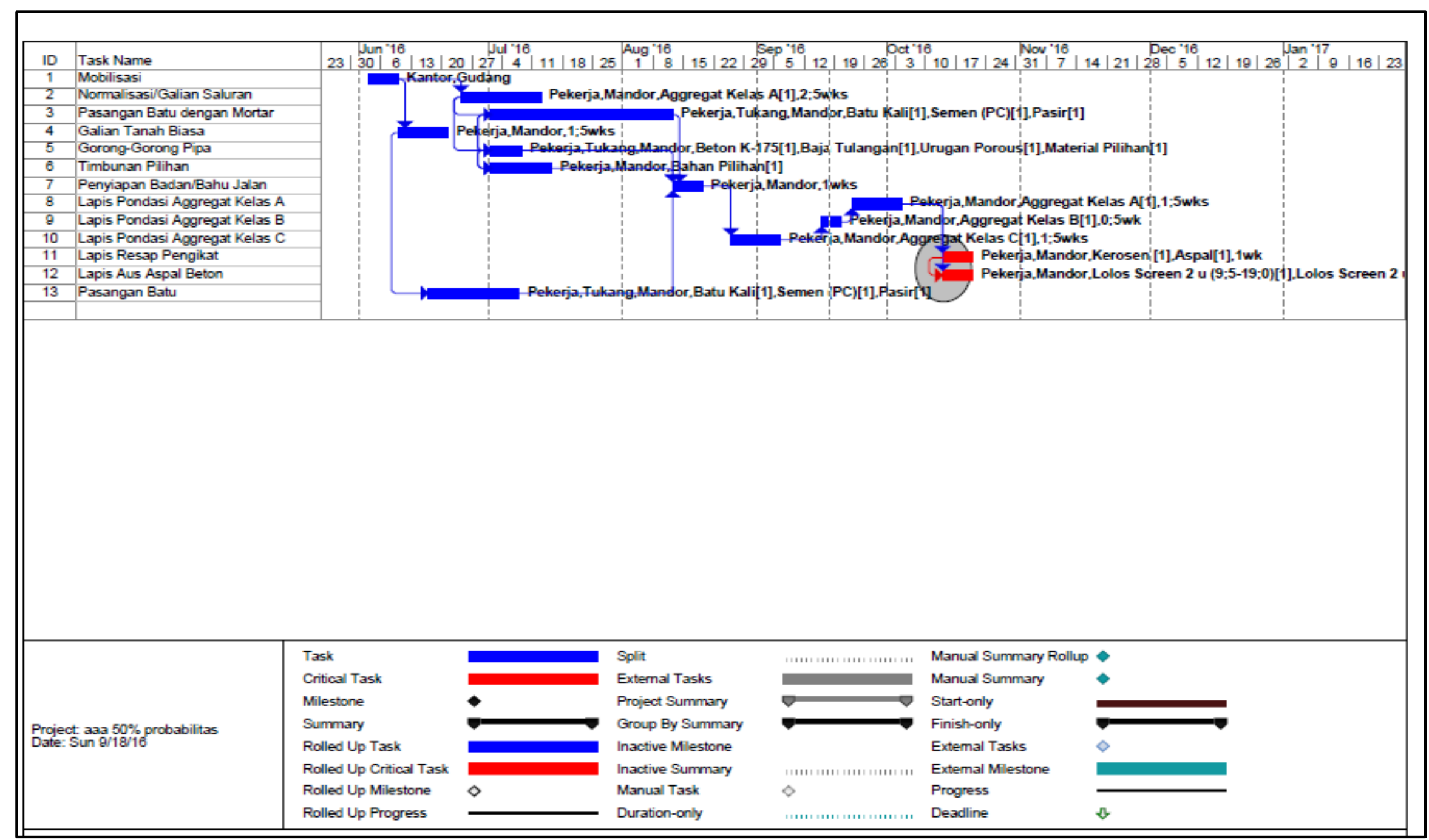

Gambar 8. Gantt Chart Konflik Sumber Daya 
Dari gambar 8 maka dapat dilihat pekerjaan yang masih dalam keaadan overlapping. Keadaan pekerjaan diatas merupakan kondisi pekerjaan yang tidak dapat digeser, karena pekerjaan lapis resap pengikat dan lapis aus aspal beton memakai sumber daya yang sama. Dengan demikian maka pekerjaan dapat dikalkulasikan kedalam penjadwalan critical chain.

Tabel 3 Task List Critical Chain Proyek

\begin{tabular}{|l|c|l|}
\hline \multicolumn{1}{|c|}{ Task Name } & $\begin{array}{c}\text { Durasi } \\
\text { (Minggu) }\end{array}$ & Predecessor \\
\hline Mobilisasi & 1 & \\
\hline $\begin{array}{l}\text { Normalisasi/Galian } \\
\text { Saluran }\end{array}$ & 2,5 & $1 \mathrm{FS}+2$ wks \\
\hline $\begin{array}{l}\text { Pasangan Batu } \\
\text { dengan Mortar }\end{array}$ & 6 & $2 \mathrm{SS}+1 \mathrm{wk}$ \\
\hline $\begin{array}{l}\text { Gorong-Gorong } \\
\text { Pipa }\end{array}$ & 1 & $\begin{array}{l}3 \mathrm{SS} ; 2 \mathrm{SS}+1 \\
\text { wk }\end{array}$ \\
\hline Timbunan Pilihan & 2 & $3 \mathrm{SS} ; 5 \mathrm{SS}$ \\
\hline $\begin{array}{l}\text { Penyiapan } \\
\text { Badan/Bahu Jalan }\end{array}$ & 2 & $\begin{array}{l}3 ; 6 \mathrm{FS}+4 \\
\text { wks; } 13\end{array}$ \\
\hline $\begin{array}{l}\text { Lapis Pondasi } \\
\text { Aggregat Kelas A }\end{array}$ & 1,5 & 9 \\
\hline $\begin{array}{l}\text { Lapis Pondasi } \\
\text { Aggregat Kelas B }\end{array}$ & 0,5 & 10 \\
\hline $\begin{array}{l}\text { Lapis Pondasi } \\
\text { Aggregat Kelas C }\end{array}$ & 1,5 & 7 \\
\hline $\begin{array}{l}\text { Lapis Resap } \\
\text { Pengikat }\end{array}$ & 1 & 8 \\
\hline $\begin{array}{l}\text { Lapis Aus Aspal } \\
\text { Beton }\end{array}$ & 1 & $8 ; 11 \mathrm{SS}$ \\
\hline Sumbr Pengolahan & $2016)$ \\
\hline
\end{tabular}

(Sumber: Pengolahan Data, 2016)

Perhitungan besaran project buffer dihitung $50 \%$ dari rantai kritis (cut and paste methode).

Tabel 4.4 Tabel Total Panjang Rantai Kritis

\begin{tabular}{|l|c|l|}
\hline \multicolumn{1}{|c|}{ Task Name } & $\begin{array}{c}\text { Durasi } \\
\text { (Minggu) }\end{array}$ & Predecessor \\
\hline Mobilisasi & 1 & \\
\hline $\begin{array}{l}\text { Normalisasi/Galian } \\
\text { Saluran }\end{array}$ & 2,5 & $1 \mathrm{FS}+2$ wks \\
\hline $\begin{array}{l}\text { Pasangan Batu } \\
\text { dengan Mortar }\end{array}$ & 6 & 2SS+1 wk \\
\hline $\begin{array}{l}\text { Gorong-Gorong } \\
\text { Pipa }\end{array}$ & 1 & $\begin{array}{l}3 \mathrm{SS} ; 2 \mathrm{SS}+1 \\
\text { wk }\end{array}$ \\
\hline Timbunan Pilihan & 2 & $3 \mathrm{SS} ; 5 \mathrm{SS}$ \\
\hline $\begin{array}{l}\text { Penyiapan } \\
\text { Badan/Bahu Jalan }\end{array}$ & 2 & $\begin{array}{l}3 ; 6 \mathrm{FS}+4 \\
\mathrm{wks} ; 13\end{array}$ \\
\hline $\begin{array}{l}\text { Lapis Pondasi } \\
\text { Aggregat Kelas A }\end{array}$ & 1,5 & 9 \\
\hline $\begin{array}{l}\text { Lapis Pondasi } \\
\text { Aggregat Kelas B }\end{array}$ & 0,5 & 10 \\
\hline $\begin{array}{l}\text { Lapis Pondasi } \\
\text { Aggregat Kelas C }\end{array}$ & 1,5 & 7 \\
\hline Lapis Resap & 1 & 8 \\
\hline
\end{tabular}

\begin{tabular}{|c|c|c|}
\hline Pengikat & & \\
\hline $\begin{array}{l}\text { Lapis Aus Aspal } \\
\text { Beton }\end{array}$ & 1 & $8 ; 11 \mathrm{SS}$ \\
\hline Total & & 20 \\
\hline
\end{tabular}

(Sumber: Pengolahan Data, 2016)

Project Buffer $=50 \% \mathrm{x}$ panjang rantai kritis

$$
\begin{aligned}
& =50 \% \times 20 \\
& =10 \mathrm{minggu}
\end{aligned}
$$

Feeding buffer disisipkan dalam penjadwalan pada persimpangan antara pekerjaan critical chain dan non critical chain. Besarnya ukuran dari feeding buffer ini dengan cara 50\% dari panjang rantai non kritis. Berikut adalah penentuan feeding buffer dalam penjadwalan critical chain pada pekerjaan non kritis:

Feeding buffer $=\sum$ durasi ( Galian Tanah Biasa + Pasangan Batu) x 50\%

$=(1,5$ minggu +3 minggu $) \times 50 \%$

$=4,5$ minggu $\times 50 \%$

$=2,25$ minggu 


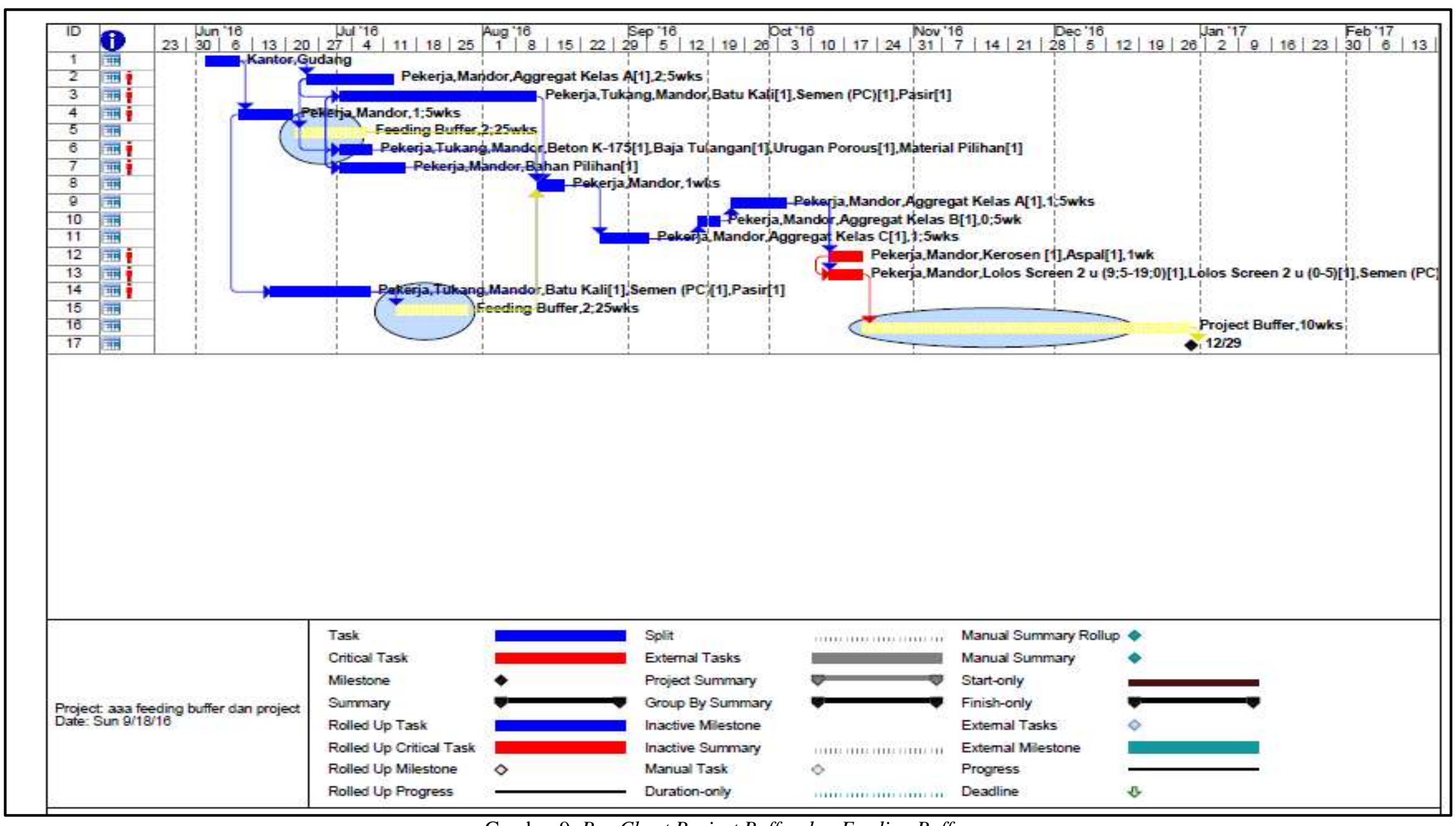

Gambar 9. Bar Chart Project Buffer dan Feeding Buffer 


\section{Kesimpulan}

Adapun kesimpulan pada laporan penelitian ini adalah:

Dari pengolahan data dan analisis yang sudah dilakukan dapat ditarik kesimpulan sebagai berikut:

Durasi optimal proyek jalan SMK IT Payakumbuh pada penjadwalan dengan menggunakan metode CCPM adalah selama 197 hari kalender apabila seluruh buffer time digunakan dimana sebelumnya jadwal perencanaan proyek selama 147 hari kalender. Namun apabila suatu aktivitas mengalami suatu hal tak terduga, tim proyek tidak perlu khawatir karena adanya waktu penyangga tersebut sehingga proyek terlindungi dari keterlambatan.

\section{Daftar Pustaka}

Arianto, A. 2010. Eksplorasi Metode Bar Chart, CPM, PDM, PERT, Line of Balance dan Time of Chainage Diagram dalam Penjadwalan Proyek Konstruksi. Tesis.

Ardani, 2009, Analisa Penerapan Manajemen Waktu Pada Proyek Konstruksi Jalan (Studi Kasus: PT. Sabaritha Perkasa Abadi, PT. Sinar Kasih Reinhard, PT. Dian Perkasa, Tugas Akhir. Universitas Sumatera Utara, Medan.

Daniati, 2012, Penjadwalan Proyek Pembangunan Rumah Sakit Pendidikan Universitas tadulako Dengan Menggunakan Microsoft Project, Tugas Akhir, Universitas Tadulako, Palu.

Dannyanti, Eka. 2010. Optimalisasi Pelaksanaan Proyek dengan Metode Pert dan CPM (Studi Kasus: Twin Tower Building Pasca Sarjana Undip). Jurnal.

Gray. C. F dan Erik. W. L. 2007. Manajemen Proyek. Yogyakarta. Andi.

Goldratt, E.M. (1997). Critical chain. Great Barrington, MA: The North River Press
Leach, L.P. (2005). Critical chain project management (2nd Ed). Norwood, MA: Artech House, INC.

Lechler, T., Ronen, B., and Stohr, E.A. (2005). Critical chain project management: High potential - hard to achieve. Stevens Institute of Technology.

Mingus, Nancy, 2004, Alpha Teach Yourself Project Management dalam 24 jam. Terjemahan oleh Triwibowo Budhi Santoso. 2004. Prenada. Jakarta.

Nasution. R. 2014. Penerapan Metode Critical Chain Project Management Untuk Perencanaan Proyek Very Low Pressure Phase-Ii Kei Ltd. Jurnal.

Raharja. I. 2014. Analisa Penjadwalan Proyek Dengan Metode PERT di PT. Hasana Damai Putra Yogyakarta pada Proyek Perumahan Tirta Sani. Jurnal.

Setiawan, M. Ikhsan, 2009, Rescheduling Waktu Pekerjaan Guna Optimasi Biaya Pembangunan Rusunawa Siwalankerto Surabaya, Jurnal Neutron, Vol. 9 No. 1. Surabaya.

Soeharto, Iman (1999), Manajemen Proyek (Dari Konseptual Sampai Operasional), Jilid I,Edisi Kedua, Erlangga, Jakarta.

[14] Soeharto, Iman, 1995, Manajemen Proyek Dari Konsepsial Sampai Operasional, Penerbit Erlangga, Jakarta.

Tilaar. T. A. M dan Yunus. M. R. 2013. Penjadwalan Proyek Pembangunan Gedung Research Centre Universitas Tadulako Dengan Menggunakan Microsoft Project. Jurnal.

Wijaya. T. V dan Witono. A. R. 2011. Studi Literatur Tentang Perkembangan Critical Chain Method. Skripsi.

Wowor. N. 2013. Aplikasi Microsoft Project Dalam Pengendalian Waktu Pelaksanaan Pekerjaan Proyek. Jurnal. 